脳動脈瘤に対するステント留置による血行力学的効果

一多孔質媒体モデルを用いた数值流体力学 (CFD) による検討一

辻 正範 ${ }^{1)}$, 石田 藤麿 ${ }^{2)}$, 古川 和博 ${ }^{1)}$, 三浦 洋一 ${ }^{3)}$, 佐野 貴則 ${ }^{4)}$, 芝 真人 ${ }^{2)}$, 種村 浩 ${ }^{2}$, 梅田 靖之 ${ }^{1)}$, 安田 竜太 ${ }^{1)}$, 当麻 直樹 ${ }^{1)}$, 霜坂 辰一 ${ }^{2}$, 鈴木 秀謙 ${ }^{1)}$

1）三重大学大学院医学系研究科脳神経外科学，2）独立行政法人国立病院機構三重中央医療セン夕ー脳神経外科，3）社会医療 法人峰和会鈴鹿回生病院脳神経外科，4）日本赤十字社伊勢赤十字病院脳神経外科

\title{
Hemodynamic Changes after placing Intracranial Stents : Computational Fluid Dynamics (CFD) Analysis using Porous Media Modeling in the Stent Domain
}

\author{
Masanori Tsuji, M.D. ${ }^{1)}$, Fujimaro Ishida, M.D., Ph.D. ${ }^{2)}$, Kazuhiro Furukawa, M.D. ${ }^{1)}$, \\ Yoichi Miura, M.D., Ph.D. ${ }^{3)}$, Takanori Sano, M.D., Ph.D. ${ }^{4}$, Masato Shiba, M.D., Ph.D. ${ }^{2)}$, \\ Hiroshi Tanemura, M.D., Ph.D. ${ }^{2)}$, Yasuyuki Umeda, M.D., Ph.D. ${ }^{1}$, Ryuta Yasuda, M.D., Ph.D. ${ }^{1}$, \\ Naoki Toma, M.D., Ph.D. ${ }^{1)}$, Shinichi Shimosaka, M.D., Ph.D. ${ }^{2)}$, and Hidenori Suzuki, M.D., Ph.D. ${ }^{1)}$ \\ 1) Department of Neurosurgery, Mie University Graduate School of Medicine, 2) Department of Neurosurgery, Mie Chuo \\ Medical Center, National Hospital Organization, 3) Department of Neurosurgery, Suzuka Kaisei Hospital, 4) Department of \\ Neurosurgery, Ise Red Cross Hospital
}

Placing a neck bridging stent or a flow diverter has enabled the endovascular treatment for a wide-necked cerebral aneurysm by changes in intra-aneurysmal local hemodynamics. Computer-aided design (CAD) has been applied to an intracranial stent to simulate endovascular treatment effects using computational fluid dynamics (CFD). However, CFD analysis with CAD techniques needs enormous time. The aim of this study was to investigate the hemodynamic changes after placing intracranial stents using CFD with porous media modeling.

The patient-specific geometry models of three unruptured internal carotid artery aneurysms with different sizes were acquired by using three-dimensional(3D) computed tomographic angiography. For each Digital Imaging and Communications in Medicine (DICOM) data, the 3D neck model was made using a Boolean subtraction of aneurysm-deleted model from original geometry model. We obtained 3D stent domain (3DSD) by the transformation in which 3D neck model was offset by a thickness of particle diameter, which corresponds to that of Enterprise VRD (Johnson \& Johnson Codman, Miami, FL, USA). Volume coverage ratio (VCR) was defined as the stent volume ratio in 3DSD. Filtration of blood through a virtual 3DSD was described by Darcy's law (porous media modeling). Hemodynamic parameters such as wall shear stress (WSS), oscillatory shear index (OSI), oscillatory velocity index (OVI), relative residence time (RRT), and flow velocity (FV) at dome were calculated by the CFD analysis. CFD simulation was achieved by changing the VCR every $10 \%$ from $0 \%$ (VCR 0.00) to 50\% (VCR 0.50).

As VCR increased, WSS and FV at dome decreased, and RRT increased in all cases. OSI and OVI in small (Case 1) and medium-sized (Case 2) aneurysms peaked at VCR 0.30 or 0.20 and then decreased, while those in a large aneurysm (Case 3) re-increased at VCR 0.5 after the first peaking and decreasing.

CFD analysis using porous media simulation revealed that an increase in VCR induced stagnant and disturbed blood flow in a short time. However, hemodynamics in a large aneurysm may be different from that of small and medium-sized aneurysms. CFD may be useful to determine the therapeutic strategy for endovascular neurosurgeons.

(Received April 21, 2016; accepted November 7, 2016)

Key words : computational fluid dynamics, porous media, cerebral aneurysm

Jpn J Neurosurg（Tokyo）26:444-451, 2017

連絡先：辻 正範, $\bar{\top}$ 514-8507 津市江戸橋 2-174 三重大学大学院医学系研究科脳神経外科学

Address reprint requests to : Masanori Tsuji, M.D., Department of Neurosurgery, Mie University Graduate School of Medicine, 2-174 Edobashi, Tsu-shi, Mie 514-8507, Japan 


\section{はじめに}

脳動脈瘤の血行力学的特徵を評価する方法として, 数 值流体力学 (computational fluid dynamics: CFD) 解析が 行われている. CFD 解析を用いた脳動脈瘤に対するステ ント留置前後での血行力学的変化についての報告は散見 する ${ }^{410)}$. ステント形状作成方法については，ステント セルの異なる形状を実際に作成し, 動脈瘤シリコンモデ ルに留置し CFD解析を行ったもの ${ }^{3)}$ や, Mut ${ }^{12)}$ や Tanemura ${ }^{15)}$ が報告したように, ステント形状をコン ピュータ支援設計 (computer aided design：CAD) や micro CT を用いて作成し CFD 解析を行ったものがある。しか し, シリコンモデルの動脈瘤では患者固有の血管形状を 再現することは困難であり，CAD や micro CT を用いた ステント形状再現は, 膨大な格子数となり, 市販されて いるコンピュータを用いて，われわれの数值モデリング で計算すると, flow diverterの CFD 解析には計算に要す る時間が問題となる。

$\mathrm{CFD}$ 解析の新たな解析方法として, 動脈嘅内を多孔質 媒体で数值リモデリングする解析方法が開発されてい る ${ }^{12)}$.そこで従来までの CFD解析での時間的課題を克服 するため, ステント領域を多孔質媒体で数值リモデリン
グし，CFD 解析を行った。ステントセルサイズの影響に ついて，多孔質媒体を用いて評価した報告はわれわれが 涉猟したかぎりでは見当たらない。そこでステントセル の縮小変化を多孔質媒体の密度変化に置換し，脳動脈瘤 内の血行力学的変化について検討した。

\section{対象と方法}

当施設の未破裂脳動脈瘤のうち，3-dimensional（3D）computed tomographic angiography（CTA）で血管形状を 獲得した内頝動脈瘤患者 3 症例を対象とした。異なる大 きさの脳動脈瘤におけるステント留置後の血行力学的変 化を脳動脈瘤の大きさごとに評価する目的で，小型 （Case 1）と中型（Case 2）の脳動脈瘤と, flow diverter の 適応となる大型（Case 3）の脳動脈溜を対象とした（Fig. 1).

患者固有形状モデルは，3 D-CTA で得られた血管形状 を Mimics innovation suite 16.0, 3-matic 8.0, Magics 17.0 (Materialise Japan，Yokohama，Japan）を用い，1 mm 未 満の血管などのトリミングとスムージングを行った後, stereolithography（STL）ファイルに変換し出力した。次 に3-matic 8.0 を用いて脳動脈痹削除モデルを作成した。

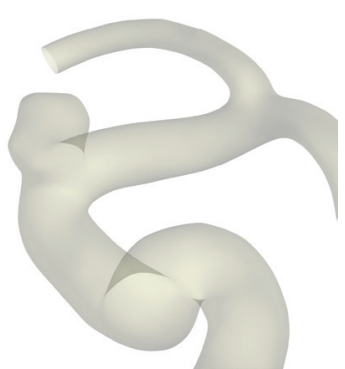

Case 1

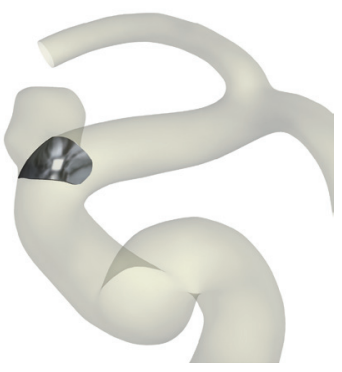

Upper group is a patient specific geometry model (PSGM), and lower group is PSGM with 3dimensional stent domain.

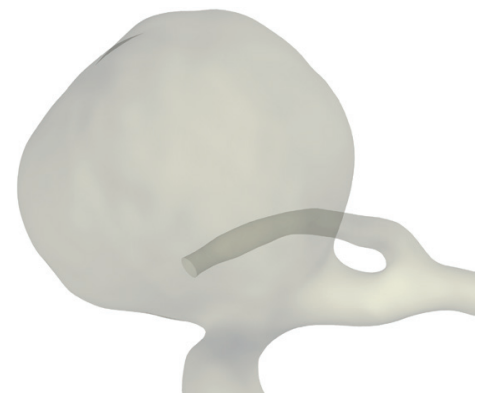

Case 3

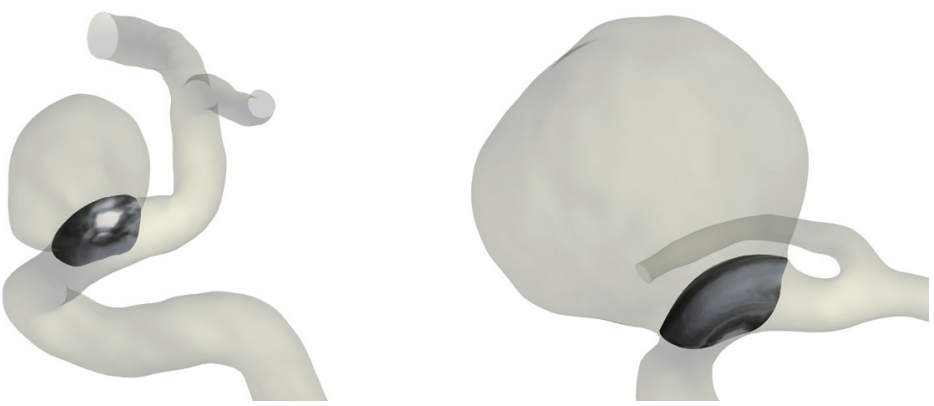

Fig. 1 Visualization of all aneurysms

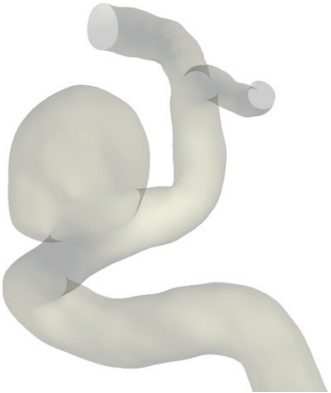

Case 2 
周囲の血管形状との歪みを小さくするために，再現され た頝部周囲の血管形状を $3 \%$ 増大させた後に, Boolean 演 算によって $3 \mathrm{D}$ neck を作成し，これを $2 \%$ 縮小した。今 回は Enterprise VRD (Johnson \& Johnson Codman, Miami，FL，USA）の素線径に対応する等価直径である $0.064 \mathrm{~mm}$ を particle diameter とする球状粒子でステント 領域を置換した。 そのため 3D neck を $0.064 \mathrm{~mm}$ で offset し, 3D stent domain（3DSD）と定義し, 多孔質媒体とし て数值モデリングした (Fig. 1). STL ファイルを ANSYS ICEM CFD16.1 (Ansys, Canonsburg, PA, USA) に取り 込み, 格子を作成した。格子は 3DSD 以外の部位では最 低 $0.1 \mathrm{~mm}$, 最大 $0.6 \mathrm{~mm}$ の 4 面体で作成し, 3DSD では 多孔質媒体の particle diameter 以下となるように 0.05 $\mathrm{mm}$ の 4 面体の格子を用いた。 さらに血管形状の表面に は 5 層の 5 面体を設定した。数值モデリング, 解析, 可 視化には ANSYS CFX 16.1（Ansys）を使用した。血液は 密度 $1,056 \mathrm{~kg} / \mathrm{m}^{3}$, 粘性率 $0.0035 \mathrm{~Pa} \cdot \mathrm{s}$ と仮定した. Time

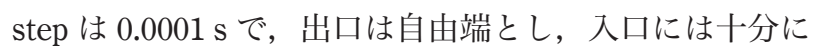
発達した層流を設定するため, 断面積の等価直径に応じ て延長した。血流量は内頝動脈の健常成人 mass flow waveform ${ }^{8)}$ で生理的な壁面剪断応力（wall shear stress： WSS）となるように，ポアズイユの法則に基づき症例ご とに計算し, 非定常解析を行った。離散化は有限体積法 で, 質量および運動量の残差は $10^{-4}$ 未満に設定した。血 流は非圧縮性ニュートン流体とし, 連続の式とナビエストークス方程式に従うと仮定した。方程式は

$$
\begin{aligned}
& \nabla \cdot \nu=d i v \cdot \nu=0 \\
& \frac{\partial \nu}{\partial t}+(\nu \cdot \nabla) \nu=-\frac{1}{\rho} \nabla p+\frac{\mu}{\rho} \nabla^{2} \nu+F
\end{aligned}
$$

で， $\nu$ は血流速度， $p$ は圧力， $\rho$ は血液密度， $\mu$ は粘性 率, $F$ は外力を示す.

ステント留置後の CFD 解析はステント留置前の血管 形状を用い，3DSD をDarcyの法則に基づいた多孔質媒 体領域に設定した。多孔質媒体領域における血流の圧力 は外力とのつり合いにより,

$$
0=-\nabla p-K \nu
$$

と表される.このとき $K$ は透化係数で多孔質媒体の抵抗 を表し，

$$
K=\alpha|\nu|+\beta
$$

と表される. 係数 $\alpha$ と $\beta$ は粒子が詰められた多孔質媒体 の圧力損失を求めるため Ergun の式 ${ }^{1 / 6)}$ によって計算さ れ,

$$
\alpha=\frac{1.75 \rho(1-\kappa)}{\kappa^{3} D_{p}}, \quad \beta=\frac{150 \mu(1-\kappa)^{2}}{\kappa^{3} D_{p}^{2}}
$$

と表される。 $D_{p}$ は粒子直径である，全例 $D_{p}$ は Enterprise
VRD の素線径に対する等価直径である $0.064 \mathrm{~mm}$ とし た．素線径という用語は通常はブレイデッドタイプのス テントに用いられるため, レザーカットタイプである Enterprise VRD には不適当な用語ではある。しかしなが ら，それに替わる用語を渉編できなかったため今回は便 宜的に素線径という用語を使用した。 3DSD 内に占めるステント体積比を volume coverage ratio （VCR）と定義すると，

$$
\kappa=1-\frac{V C R}{100}
$$

となる。これまで研究で Enterprise VRD と Pipeline Embolization Device (ev3/Coviden, Irvine, CA, USA) の surface metal area coverage はそれぞれ $0.10,0.30$ と想 定されている ${ }^{14)}$. VCRを 0 (VCR 0.00) から 0.1 ずつ変 化させ, 現在臨床応用されている flow diverter の VCR を 超えた領域（VCR 0.50）まで変化させた際の各種血行力 学的パラメー夕を非定常解析で求めた。

形態学的パラメータ (Fig. 2) を計算し, 動脈瘤内の WSS, WSS 関連血行力学的パラメータ, 三次元血流量領 域関連速度ベクトル関連パラメー夕, 瘤内の平均血流速 度 (flow velocity：FV) について, VCR 変化との関係性 を評価した。

\section{結 果}

形態学的パラメー夕を Table 1 に示す. 血行力学的パ ラメータでは, 3 症例すべてで VCR 増加に伴い WSS と FV は低下し, 動脈瘤内のうつ滞を示す relative residence time $(\mathrm{RRT})^{9)}$ は増加した (Table 2). WSS ベクトルと FV ベクトルの時間依存性の摇らぎを示すパラメータである oscillatory shear index (OSI) ${ }^{16)}$ と oscillatory velocity index $(\mathrm{OVI})^{11)}$ は, Case 1 では VCR 0.30, Case 2 では VCR 0.20 をピークとし, その後低下した。一方, 大型 (Case 3) の 動脈瘤の OSI と OVI は VCR 0.20 でピークとなった後, VCR 0.40 まで低下し, VCR 0.50 で再増加した. Case 3 の WSS, 三次元流線, OSI, OVI と RRT を VCR 0.00 と VCR 0.50 において可視化したものを示す (Fig. 3，4). VCR 0.50 では3DSD を通過して血流が流入しない様子が確認 できた。

\section{考 察}

コイル塞栓術に対する CFD 解析の新たな評価方法と して, 動脈瘤内を多孔質媒体で数值モデリングし, コイ ル塞栓術をシミュレーションする試みが行わ扎てい 

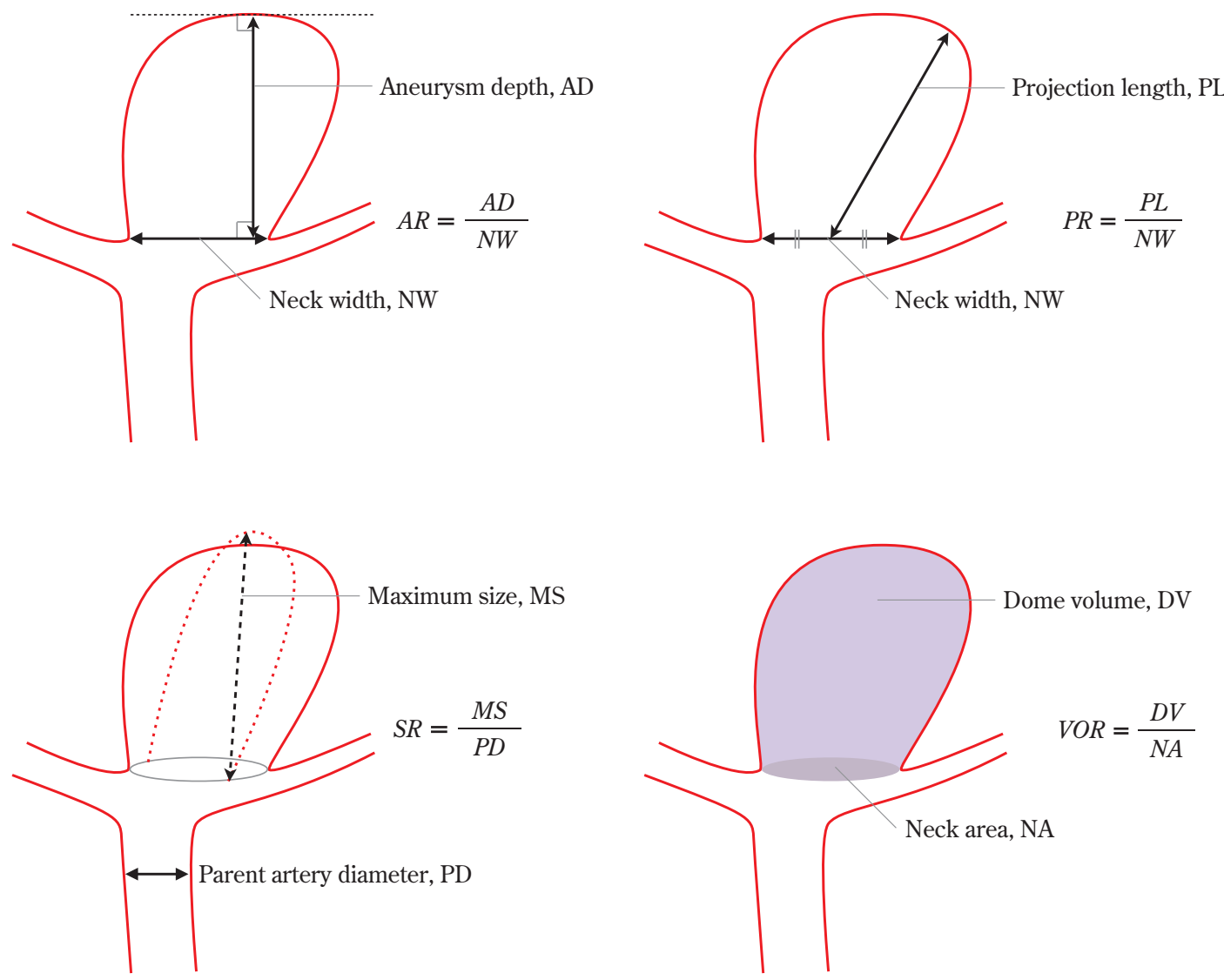

Fig. 2 Schema of aneurysm dimensions and shape indices

$\mathrm{AR}$ : aspect ratio, $\mathrm{PR}$ : projection ratio, $\mathrm{SR}$ : size ratio, $\mathrm{VOR}$ : volume-to-ostium area ratio

$3^{13)}$ ，多孔質媒体を使用し，瘤内残存血流体積を求める ことでコイル塞栓術後の再発予測が可能になる，と梅田 ら ${ }^{17)}$ は報告した。

広い頝部の脳動脈瘤母血管にステントを留置し，コイ ルが逸脱しないようにしながら脳動脈瘤を塞栓するステ ントアシストテクニックとして neck bridging stent が広 く使用されている。 また, neck bridging stentよりはるか にステントセルが細かいステントで, 脳動脈瘤䅡部をカ バーし瘤内の血流を大きく変化させることにより脳動脈 瘤を血栓化させる flow diverter（neck occlusion stent）が

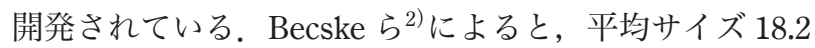
$\mathrm{mm}$ の脳動脈瘤 106 例に対して flow diverterの Pipeline embolization deviceを使用した結果, $73.6 \%$ で完全閉塞が 得られた。一方で，重大な合併症として delayed rupture があり，その発生率は $1.75 \%$ と報告された ${ }^{18)}$. Cebral ら ${ }^{4)}$ は flow diverter 留置後に delayed rupture をきたした症例 で CAD ステントを用いて CFD 解析を行い, ステント留 置後に脳動脈瘤内压が $20 \mathrm{mmHg}$ 以上上昇したことを報 告した。しかし, Cebral らの報告に対しては，圧勾配や
Table 1 Summary of morphological parameters

\begin{tabular}{l|c|c|c}
\hline \multicolumn{1}{c|}{ Morphological parameters } & Case 1 & Case 2 & Case 3 \\
\hline Aneurysm depth, mm & 3.78 & 7.26 & 14.36 \\
Projection length, mm & 3.91 & 7.48 & 14.63 \\
Maximum size, mm & 5.19 & 9.32 & 20.58 \\
Neck width, mm & 3.58 & 6.05 & 14.29 \\
Parent artery diameter, mm & 3.71 & 3.34 & 3.50 \\
Aspect ratio & 1.06 & 1.20 & 1.00 \\
Projection ratio & 1.09 & 1.24 & 1.02 \\
Size ratio & 1.40 & 2.79 & 5.87 \\
Neck area, $\mathrm{cm}^{2}$ & 0.11 & 0.30 & 1.40 \\
Dome area, $\mathrm{cm}^{2}$ & 0.50 & 1.94 & 8.73 \\
Dome volume, $\mathrm{cm}^{3}$ & 0.04 & 0.30 & 2.87 \\
VOR, mm & 3.74 & 9.90 & 20.55 \\
\hline
\end{tabular}

VOR: volume-to- ${ }^{-}$stium area ratio

flow diverter 留置による動脈溜中枢側の脳動脈狭窄の解 除に伴う血流量の上昇を過剩評価している点などに批判 があり, flow diverter 留置後に脳動脈瘤内の圧上昇が生 じるか否かについては意見の一致をみていない7. また 
Table 2 Summary of hemodynamic parameters

\begin{tabular}{l|c|c|c|c|c|c}
\hline & VCR 0.00 & VCR 0.10 & VCR 0.20 & VCR 0.30 & VCR 0.40 & VCR 0.50 \\
\hline WSS, Pa & & & & & & \\
Case 1 & 4.555 & 1.641 & 0.413 & 0.127 & 0.048 & 0.024 \\
Case 2 & 1.082 & 0.441 & 0.070 & 0.013 & 0.004 & 0.002 \\
Case 3 & 2.944 & 1.516 & 0.292 & 0.033 & 0.006 & 0.002 \\
FV, m/sec & & & & & & \\
Case 1 & 0.197 & 0.092 & 0.029 & 0.011 & 0.004 & 0.002 \\
Case 2 & 0.077 & 0.044 & 0.013 & 0.003 & 0.001 & 0.001 \\
Case 3 & 0.133 & 0.095 & 0.042 & 0.011 & 0.003 & 0.001 \\
OSI & & & & & & \\
Case 1 & 0.002 & 0.017 & 0.018 & 0.020 & 0.016 & 0.008 \\
Case 2 & 0.005 & 0.015 & 0.029 & 0.019 & 0.011 & 0.010 \\
Case 3 & 0.014 & 0.019 & 0.042 & 0.040 & 0.018 & 0.038 \\
OVI & & & & & & \\
Case 1 & 0.002 & 0.009 & 0.008 & 0.010 & 0.008 & 0.004 \\
Case 2 & 0.006 & 0.013 & 0.023 & 0.009 & 0.004 & 0.004 \\
$\quad$ Case 3 & 0.031 & 0.036 & 0.045 & 0.033 & 0.011 & 0.017 \\
RRT, $\times 10^{-2} \mathrm{~Pa}^{-1}$ & & & & & & \\
Case 1 & 0.003 & 0.013 & 0.068 & 0.219 & 0.741 & 1.667 \\
Case 2 & 0.013 & 0.036 & 0.259 & 1.531 & 5.256 & 11.010 \\
Case 3 & 0.009 & 0.016 & 0.087 & 0.627 & 2.700 & 7.917 \\
\hline
\end{tabular}

WSS : wall shear stress, FV : flow velocity, OSI : oscillatory shear index, OVI : oscillatory velocity index, RRT : relative residence time

A

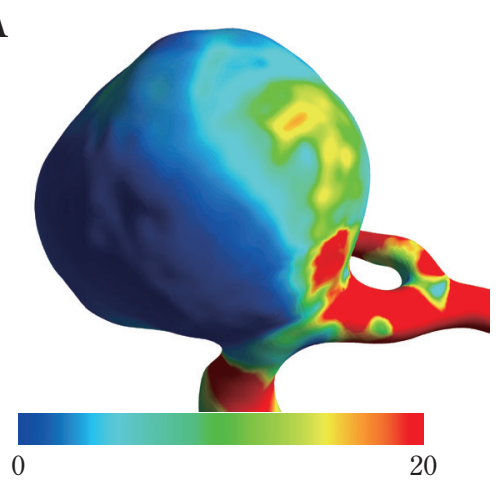

$[\mathrm{Pa}]$
B

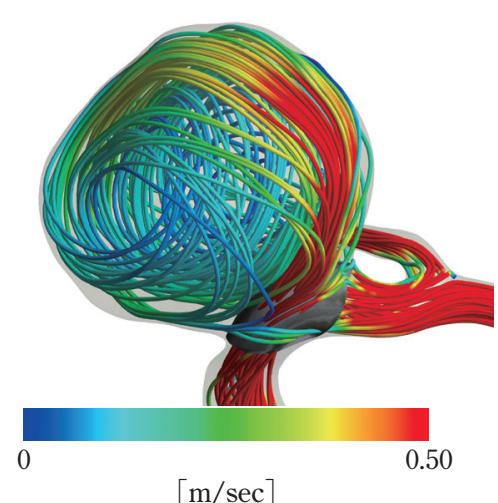

$[\mathrm{m} / \mathrm{sec}]$
C

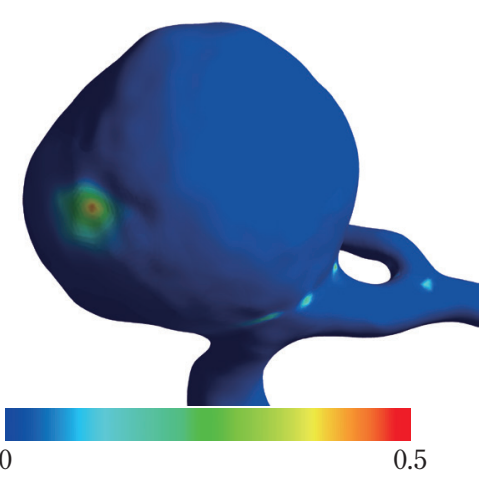

D

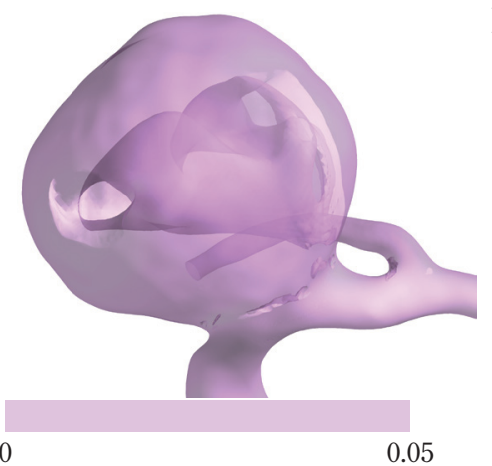

$\mathbf{E}$

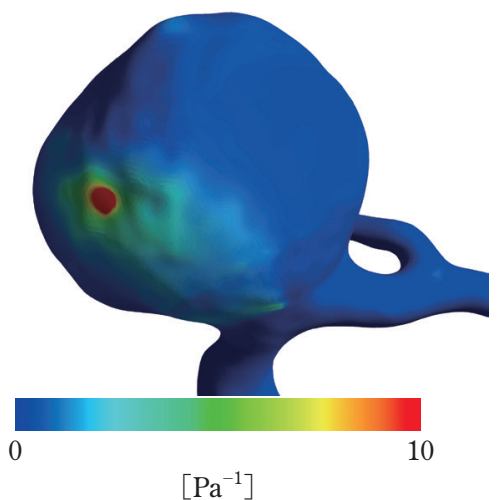

Fig. 3 WSS (A), 3D streamline (B), OSI (C), OVI (D), and RRT (E) of representative large internal cerebral artery aneurysm (Case 3 ) with the volume coverage ratio of 0.00 . 


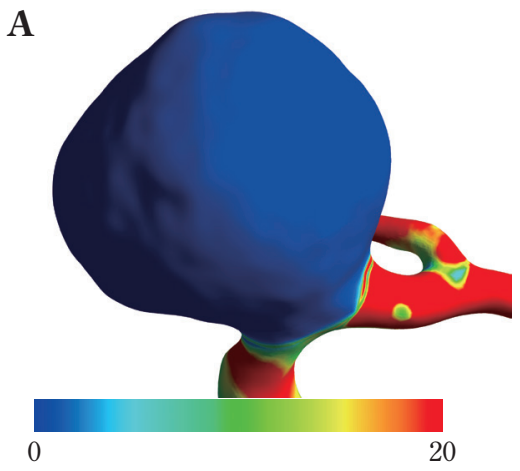

$[\mathrm{Pa}]$

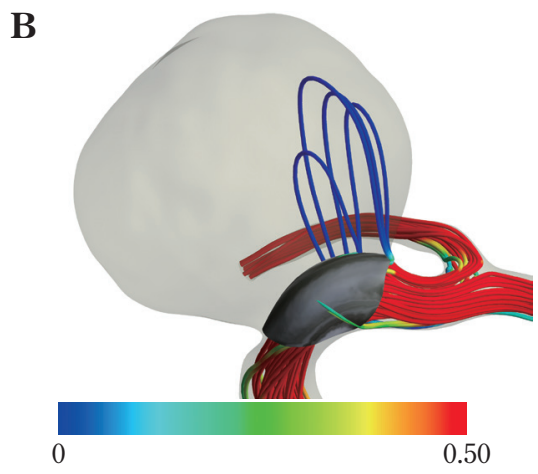

$[\mathrm{m} / \mathrm{sec}]$

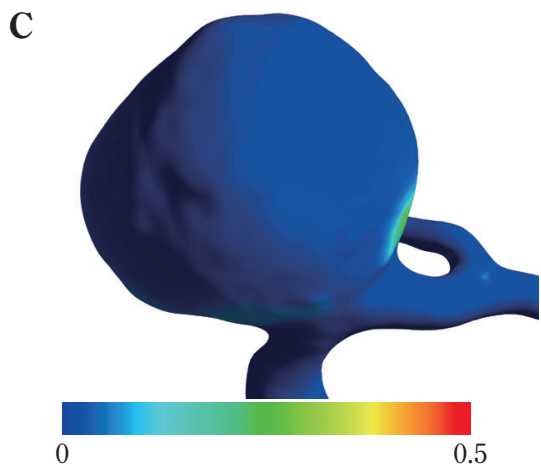

$\mathbf{E}$

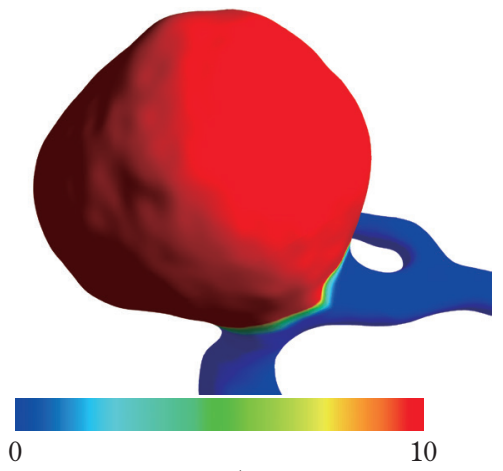

$\left[\mathrm{Pa}^{-1}\right]$

Fig. 4 WSS (A), 3D streamline (B), OSI (C), OVI (D), and RRT (E) of representative large internal cerebral artery aneurysm (Case 3$)$ with the volume coverage ratio of 0.50 .

delayed rupture と WSSやその他の血行力学的パラメータ との関連についての報告はない. CADを用いた neck bridging stent のCFD 解析はこれまでも行われているが, 同様の方法で flow diverter を再現しょうとすると，より 小さいサイズの格子が必要となる。このため計算時間は 長時間となり，臨床応用は困難になる可能性が高い.

このように従来法の CFD 解析を用いて flow diverter 留 置後の脳動脈瘤内の血行力学的変化を予想するのには限 界があった。しかし，今回われわれが用いた多孔質媒体 を用いた検討では, 定常解析は 20 分以内, 非定常解析は 15 時間以内で計算できた。

今回の結果からは, VCR 増加に伴い動脈瘤内の WSS と FV は低下した. Case 1 と Case 2 では OSI と OVI は VCR が 0.20 から 0.30 の間で増加のピークを迎えその後 低下した. Case 3 ではVCR 0.40 で低下した後に VCR 0.50 で再増加を認めた。 RRT 増加はステント留置後の瘤 内血流うつ滞を意味し, Cebral らが mean aneurysm transit time(MATT)の上昇として報告した内容と一致する ${ }^{5)}$. おのおののパラメー夕はVCR 増加に伴い徐々に増加, または減少する傾向にあった。小型（Case 1) や中型
（Case 2）動脈瘤と異なる血行力学的変化としては, 大型 (Case 3) 動脈瘤では OSI と OVI が VCR 0.20 で一度ピー クとなり, VCR 0.40 で低下し, VCR 0.50 で再増加した。 これはステント留置を考慮する際に, flow diverterの適 応となる大型動脈瘤では，小型や中型動脈瘤と比してス テント留置後の血行力学的変化は一様ではなく, 結果と して脳動脈瘤内の血栓化には異なる機序が潜在している 可能性が示唆された. VCR変化に伴う脳動脈瘤内の血行 力学的変化を短時間で詳細に検討することができること が，多孔質媒体を用いた CFD 解析の特徵である.

多孔質媒体モデルを用いた CFD 解析の課題として, 実 際にステントを親動脈に留置した際に, 親動脈の血管形 状によりステントが十分に拡張できず， surface metal area coverage が変化する影響について十分に検証されて いない点がある。 また，今回は全例で Enterprise VRD の ステントストラットの素線径に対する等価直径を用いて 多孔質媒体を作成したが，使用する neck bridging stentや flow diverter ごとに多孔質媒体粒子の等価直径を変更す る必要性が考えられる。今回は 3DSD を Darcyの法則に 基づいた多孔質媒体領域に設定した。粒子画像流速測定 
法（particle imaging velocimetry）を用いた研究3)では, 多孔質媒体を用いた CFD 解析の結果は, high porosity （VCR が 0.10 程度）の場合, Darcy の法則では解の妥当 性が低くなる可能性が示唆されている. 今回の解析方法 を臨床の場で用いて, 治療効果を含めて解の妥当性を検 討する必要がある。

今回の研究では, 多孔質媒体を用いた CFD 解析によ り, ステントセルの縮小変化による血行力学の変化が明 らかになった。これらの結果を基にして, 脳動脈留に対 する flow diverter 留置後の術後再開通や delayed rupture などの術前予測に応用できるようにさらに改良する予定 である。また, neck bridging stent 症例において, 脳動脈 瘤ドームおよびステント領域を 2 種類の多孔質媒体で設 定することで, 血行力学による脳動脈瘤コイル塞栓術の 詳細な術前シミュレーションが可能になることが期待さ れる。

著者全員は日本脳神経外科学会への COI 自己申告の登録を 完了しています。

本論文に関して開示すべき COI はありません.

\section{文 献}

1) Akgiray O, Saatçi AM : A new look at filter backwash hydraulics. Water Sci Technol 1: 65-72, 2001.

2) Becske T, Kallmes DF, Saatci I, McDougall CG, Szikora I, Lanzino G, Moran CJ, Woo HH, Lopes DK, Berez AL, Cher DJ, Siddiqui AH, Levy EL, Albuquerque FC, Fiorella DJ, Berentei Z, Marosfoi M, Cekirge SH, Nelson PK : Pipeline for uncoilable or failed aneurysms : results from a multicenter clinical trial. Radiology $267: 858-868,2013$.

3) Bouillot P, Brina O, Ouared R, Lovblad KO, Farhat M, Pereira $\mathrm{VM}$ : Hemodynamic transition driven by stent porosity in sidewall aneurysms. J Biomech 48: 1300-1309, 2015.

4) Cebral JR, Mut F, Raschi M, Scrivano E, Ceratto R, Lylyk P, Putman CM : Aneurysm ruptured following treatment with flow-diverting stents : computational hemodynamics analysis of treatment. AJNR Am J Neuroradiol $\quad 32: 27-33,2011$.

5) Cebral JR, Mut F, Raschi M, Hodis S, Ding YH, Erickson BJ, Kadirvel R, Kallmes DF : Analysis of hemodynamics and aneurysm occlusion after flow-diverting treatment in rabbit models. AJNR Am J Neuroradiol 35 : 1567-1573, 2014.

6) Ergun S: Fluid flow through packed columns. Chem Eng Prog 48: 85-94, 1952.

7) Fiorella D, Sadasivan C, Woo HH, Lieber B : Regarding
"Aneurysm rupture following treatment with flow-diverting stents: computational hemodynamics analysis of treatment”. AJNR Am J Neuroradiol 32: E95-97, 2011.

8) Ford MD, Alperin N, Lee SH, Holdsworth DW, Steinman DA : Characterization of volumetric flow rate waveforms in the normal internal carotid and vertebral arteries. Physiol Meas 26: 477-488, 2005.

9) Himburg HA, Grzybowski DM, Hazel AL, LaMack JA, Li $\mathrm{XM}$, Friedman MH : Spatial comparison between wall shear stresss measures and porcine arterial endothelial permeability. Am J Physiol Heart Circ Physiol 286 : 1916-1922, 2004.

10) Huang Q, Xu J, Cheng J, Wang S, Wang K, Liu JM : Hemodynamic changes by flow diverters in rabbit aneurysm models : a computational fluid dynamic study based on microcomputed tomography reconstruction. Stroke $\quad 44: 1936^{-}$ 1941, 2013.

11）石田藤麿，辻 正範，三浦洋一，佐野貴則，芝 真人， 種村 浩, 梅田靖之, 霜坂辰一, 鈴木秀謙: 数值流体力 学 (Computational fluid dynamics) 解析を用いた脳動脈瘤 の新しい理解一 3 次元血流領域の新しいパラメータによ る複雑な血流の定量化の試み一。主重医報 $636: 28^{-}$ 30, 2013.

12) Mut F, Cebral JR: Effects of flow-diverting device oversizing on hemodynamics alteration in cerebral aneurysms. AJNR Am J Neuroradiol 33: 2010-2016, 2012.

13) Otani T, Nakamura M, Fujinaka T, Hirata M, Kuroda J, Shibano K, Wada S : Computational fluid dynamics of blood flow in coil-embolized aneurysms : effect of packing density on flow stagnation in an idealized geometry. Med Biol Eng Comput 51: 901-910, 2013.

14) Roszelle BN, Gonzalez LF, Babiker MH, Ryan J, Albuquerque FC, Frakes DH: Flow diveter effect on cerebral aneurysm hemodynamics : an in vitro comparison of telescoping stents and the Pipeline. Neuroradiology $55: 751-758$, 2013.

15) Tanemura $H$, Ishida F, Miura $Y$, Umeda $Y$, Fukazawa $K$, Suzuki H, Sakaida H, Matsushima S, Shimosaka S, Taki W : Changes in hemodynamics after placing intracranial stents. Neurol Med Chir (Tokyo) $53:$ 171-178, 2013.

16) Taylor CA, Hughes TJ, Zarins $\mathrm{CK}$ : Finite element modeling of three-dimensional pulsatile flow in the abdominal aorta: relevance to atherosclerosis. Ann Biomed Eng 26:975987, 1998.

17）梅田靖幸，石田藤䗪，辻 正範，古川和博，佐野貴則， 当麻直樹, 阪井田博司, 霜坂辰一, 鈴木秀謙: 多孔質媒 体モデルを用いた CFD 解析による脳動脈コイル塞栓術 後閉塞状態の予測. JNET 2:69-77, 2015.

18) Wong GK, Kwan MC, Ng RY, Yu SC, Poon WS : Flow diverters for treatment of intracranial aneusysms : current status and ongoing clinical trials. J Clin Neurosci 18: 737-740, 2011. 


\section{脳動脈瘤に対するステント留置による血行力学的効果 \\ 一多孔質媒体モデルを用いた数值流体力学 (CFD) による検討一}

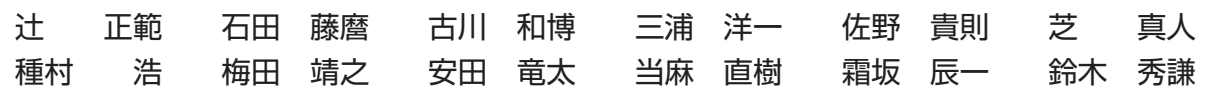

ステント留置による脳動脈瘤内の血行力学的変化を, より短時間で数值流体力学を用いて解析する ため, ステント領域を多孔質媒体でシミュレーションし, ステントセルの変化を多孔質媒体の密度变 化に置換する手法を試みた. その結果, 動脈瘤の大きさにかかわらずステントセルが縮小するほど, 瘤内の血流低下とうっ滞が生じることが明らかになった. 一方, 血流の複雑性を示すパラメータはス テントセルの縮小に伴い小型や中型動脈瘤ではいったん増加した後に減少したが, 大型動脈瘤ではさ らにステントセルが縮小すると再増加した. Flow diverter の適応となる大型動脈瘤では, 小型や中型 瘤と比べ, ステント留置後の血行力学的変化はより複雑であることが示唆された.

脳外誌 $26 ： 444-451,2017$

\section{Editorial Comment}

\section{脳神経外科領域におけるコンピュータシミュレーション}

近年 Flow Diverter（FD） deviceの開発により，血 流の整流効果のみで大きな脳動脈瘤を治療すること が可能になりつつある．日本でも FD が臨床導入さ れ, 欧米を凌ぐ治療成績も報告されている。一方で, 術後の delayed rupture や血栓化しない脳動脈瘤など の問題も明らかになってきた。このような問題は, 数值流体力学 (CFD) シミュレーションを行うこと により予測できる可能性がある。

本論文では，実際の臨床現場で使えるように計算 時間を短くする取り組みとして，実際のステントを 留置するのではなく，そのステントと同様のポーラ スメディア (多孔質媒体) を留置することでシミュ レーション時間を短くする目的の論文である。臨床 に実際使用するには，実際のステントでのシミュ レーションモデルと数值比較による精度検証が必要
東京慈恵会医科大学脳神経外科 村山雄一

だが今後の技術進歩次第で臨床応用は十分に考えら れる。

日本においても，“改正薬事法”すなわち「医薬品 医療機器等法」が施行された。同法では, 医療機器 に組み込まれていないソフトウエア（単体プログラ ム）を医療機器の範囲に加えることが新たに揭げら れ, このような数值流体力学解析ソフトウエアも臨 床シミュレーションとして臨床応用される可能性が 高く注目されている分野である。ここ数年, 数值流 体力学を用いた医学論文が急激に増えている現状も あり，われわれ医師も数值流体力学がわからないと は言えない時代が来るのも近いのかもしれない.こ のような論文報告は, 今後の臨床に役立つ重要な研 究になっていくと考元る. 